\title{
EXPERIMENTAL TESTS ON PERSONAL SAFETY DEVICES FOR FALLS FROM HEIGHT
}

\author{
JUAN CARLOS POMARES ${ }^{1}$, ELENA ÁNGELA CARRION ${ }^{2}$, RAMÓN IRLES $^{1}$, \\ ANTONIO GONZÁLEZ ${ }^{1} \&$ ENRIQUE GONZALO SEGOVIA ${ }^{1}$ \\ ${ }^{1}$ Civil Engineering Department, Alicante University, Spain \\ ${ }^{2}$ Building \& Urban Development, Alicante University, Spain
}

\begin{abstract}
Fall arrest systems are regulated according to EN-363 to retain people safely after a free fall. It is causing any significant damage during the retention process. This study is a development in performance testing of fall arrest systems. It analyses the variables that affect the behaviour of the system: fall height and the absorbed energy by devices. In this research, several experimental tests on personal safety devices are carried out. These devices are tested statically and also by dynamic tests with different fall factor (fall height/rope length) following the standards EN-354, 355, 362, 363 and 364.
\end{abstract}

Keywords: personal fall protection systems, fall arrest systems, impact test, lanyard, energy absorber.

\section{INTRODUCTION}

Falls from height are one of the main causes of serious and fatal work accidents. According to statistics from the Ministry of Employment and Social Security of the Government of Spain in 2017 there have been 20,463 accidents due to falling from height, of which 19,796 were minor, 619 serious and 48 fatal. Analysing serious accidents at work, during 2017 there were 3,505 serious accidents at work, of which 619 were due to falls from height; serious accidents due to falling height represent $17.66 \%$ of the total of serious accidents. If fatal work accidents are analysed, in the year 2017 there were 451 fatal accidents, of which 48 were due to height falls, fatal accidents due to falling height represent $10.64 \%$ of the total of fatal accidents.

This study presents the results of several dynamic tests of simplified fall arrest systems (Fig. 1) in accordance with EN-363 [1], lanyards with different free fall distance and systems with and without energy absorber. The standards all employ a 100 or $128 \mathrm{~kg}$ mass for dynamic testing. Requirement of current safety standards are shown at Table 1.

The first studies found dedicated to the physical analysis of the arrest of a fall in the analytical way were made by several researchers independently in 1977, Wang [2], Steinberg [3] and Microys [4]. They determined the maximum arrest force for a fall arrest system consisting of a lanyard and a rigid mass (ballast). They obtained a valid expression in proportional elastic behavior.

Later, in 1981, combining empirical and analytical analysis, Sulowski [5] developed a formula regarding a fall arrest system with more components (harness, absorber and sliding fall arrest device):

The fall factor (Fig. 2) that was obtained by Sulowski, relates the height of fall (kinetic energy) to the length of the rope (stiffness of the system).

It is remarkable the work in the empirical field of biodynamic made in 1990 in H.G. Amstrong Aerospace Medical Research Laboratory, Brinkley and Sulowski [6], in whose trials on volunteer's relevant data on the stop phenomenon was obtained.

In recent decades some works of a mixed nature (theoretical-experimental) have begun to be published in the field of security in construction and in others with similar problems of 
70 Structures Under Shock and Impact XV

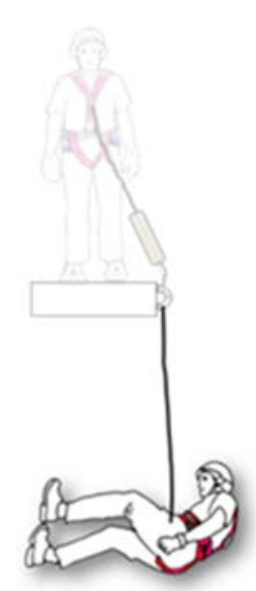

Figure 1: Fall arrest system.

Table 1: Actual standards safety requirements.

\begin{tabular}{|c|c|c|c|c|c|c|c|c|}
\hline Standards & Type & $\begin{array}{l}h \text { fall } \\
(\mathrm{m})\end{array}$ & $\begin{array}{c}\text { Fall } \\
\text { factor }\end{array}$ & $\begin{array}{l}\text { No of } \\
\text { falls }\end{array}$ & $\begin{array}{c}\text { Mass } \\
(\mathbf{k g})\end{array}$ & $\begin{array}{l}\text { Energy absorber } \\
\text { yielding }(\mathrm{kN})\end{array}$ & $\begin{array}{c}\text { Maximum } \\
\text { extension of the } \\
\text { energy absorber } \\
(\mathbf{m})\end{array}$ & $\begin{array}{l}\text { Maximum } \\
\text { arrest } \\
\text { force }(k N)\end{array}$ \\
\hline $\begin{array}{c}\text { ANSI A10.32 } \\
2004[15]\end{array}$ & - & 3.60 & 2 & 1 & 100 & $>2$ & 1.10 & $\begin{array}{c}6.2 \\
(4.5 * 1.4) \\
\end{array}$ \\
\hline $\begin{array}{c}\text { ANSI Z359.1 } \\
2007[16]\end{array}$ & - & 1.80 & 1 & 1 & 100 & $>2$ & 1.07 & 8.0 \\
\hline \multirow{2}{*}{$\begin{array}{c}\text { ANSI Z359.13 } \\
2009[17]\end{array}$} & $\begin{array}{c}6 \mathrm{ft} \\
\text { free fall }\end{array}$ & 1.80 & 1 & 1 & 128 & $>2$ & 1.22 & 8.0 \\
\hline & $\begin{array}{c}12 \mathrm{ft} \\
\text { free fall }\end{array}$ & 3.60 & 2 & 1 & 128 & $>2$ & 1.52 & 8.0 \\
\hline \multirow{2}{*}{$\begin{array}{c}\text { ISO } 10333-2 \\
{[18]}\end{array}$} & Type 1 & 1.80 & 1 & 1 & 100 & $>2$ & 1.20 & 4.0 \\
\hline & Type 2 & 4.00 & 2 & 1 & 100 & $>2$ & 1.75 & 6.0 \\
\hline $\begin{array}{l}\text { UNE-EN } \\
355 \text { [19] }\end{array}$ & - & 4.00 & 2 & 1 & 100 & $>2$ & 1.75 & 6.0 \\
\hline
\end{tabular}

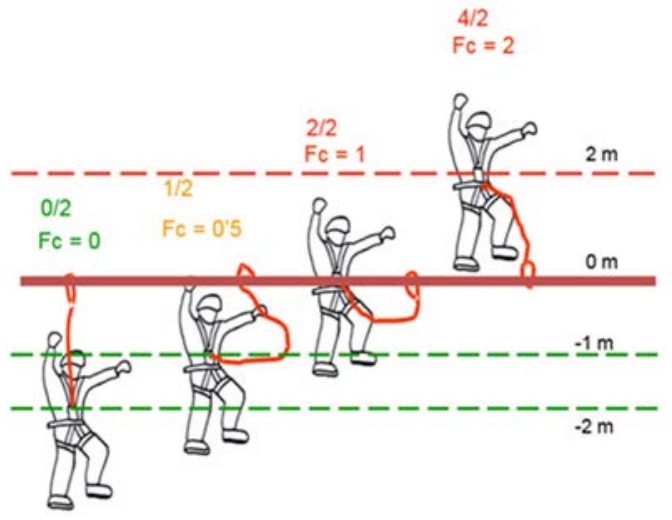

Figure 2: Fall factor Fc. 
retention of persons; among them, and in relation to the systems of collective protection against falls, the works of Irles et al. [7] and Segovia et al. [8] and Segovia [9] on safety nets, and Pomares et al. [10]-[12] on provisional edge protection systems. In 2016 the works of Carrión et al. [13], [14] with finite elements calculations on fall arrest systems provide relevant data of the arrest process of a fall obtaining maximum values of accelerations and arrest forces.

Experimental tests lead to quantify strain and strength of safety devices. In addition, the maximum force that a worker would suffer in a hypothetical accident is obtained. This maximum force is directly related to the maximum acceleration that a person would support during the retention process.

Moreover, tests facilitate numerical model's calibration of these safety devices. Calibrated numerical models allow to analyse many variables in a simpler way than with the experimental tests (always experimental tests are more expensive).

The research carried out allows us to propose modifications to the current standards, to create new designs of safety devices and to improve existing devices reducing the impact factors to reasonable values that prevent serious injuries for workers.

\section{TEST SAMPLES}

All test samples were according to the European Standards; the specifications of lanyard, energy absorber and connectors are described here (Fig. 3).

Lanyards used on tests are in accordance with European Standard EN-354 [20]. This technical specification sets out requirements, test apparatus, test methods, marking and information supplied by the manufacturer for lanyards.

Specifications:

Certification: CE EN-354, EN-358.

Material: polyester, polypropylene.

Diameter: $12 \mathrm{~mm}$.

Static strength: $22 \mathrm{kN}$.

Energy absorbers used on tests are in accordance with European Standard EN-355 [19]. This technical specification sets out requirements, test apparatus, test methods, marking and information supplied by the manufacturer for energy absorbers.

Specifications:

Certification: CE EN-355.

Material: Polyester $44 \mathrm{~mm}$ wide.

Connectors used on tests are in accordance with EN-362 [21]. This technical specification sets out requirements, test apparatus, test methods, marking and information supplied by the manufacturer for connectors.

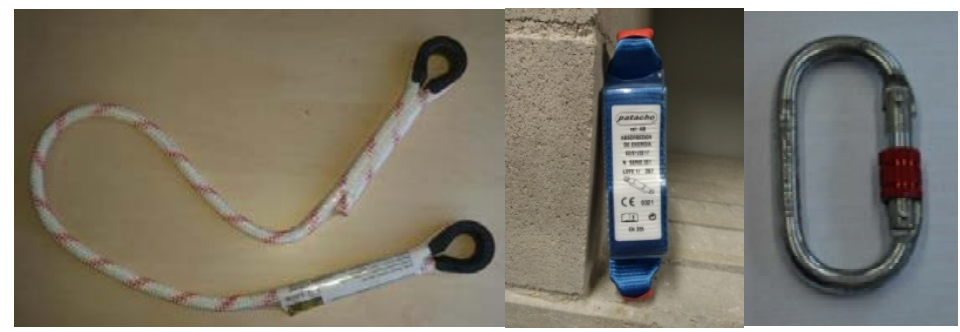

Figure 3: Test samples (lanyard, energy absorber and connector). 
Specifications:

Certification: CE EN 362.

Material: steel.

Major axis strength $25 \mathrm{kN}$.

Minor axis strength $8 \mathrm{kN}$.

Open gate strength $7 \mathrm{kN}$.

\section{TEST APPARATUS}

\subsection{Structural support}

The structural suport (Fig. 4) has been designed by the authors of this paper. Natural vibration frecuency at anchorage point on the vertical axis is near $100 \mathrm{~Hz}$ and it has a deflection lower than $1 \mathrm{~mm}$ for a a vertical load of $20 \mathrm{kN}$.

\subsection{Anchorage point}

The placement of a spherical steel ball joint (Fig. 5) at the point of greatest forces on the gantry will allow the free-form oscillation of the individual fall protection systems during the dynamic tests established according to with EN-364 [22].

\subsection{Rigid mass}

The rigid mass was made of steel, diameter $200 \mathrm{~mm}$. and hard and smooth surface. It simulates the mass of a person during his fall. The chosen removable design allows different configurations (in a range from 50 to $150 \mathrm{~kg}$ ) by adding mass progressively (Fig. 6). This configuration of the ballast allowed us to do tests with less mass for the previous adjustment of the equipment of data acquisition and lifting systems. According to EN-363 the mass required in the tests is $100 \mathrm{~kg}$ for dynamic performance test procedure.

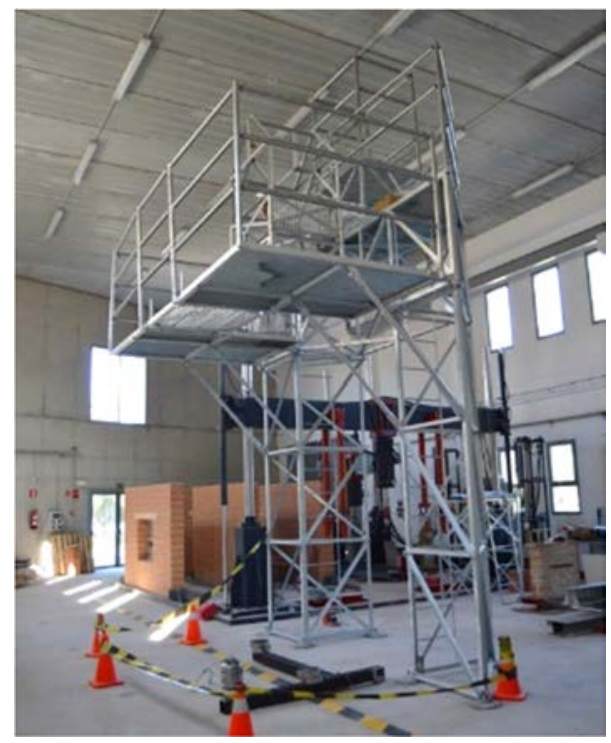

Figure 4: Structural support. 


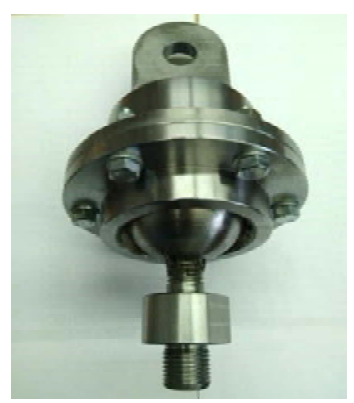

Figure 5: Spherical steel ball joint.
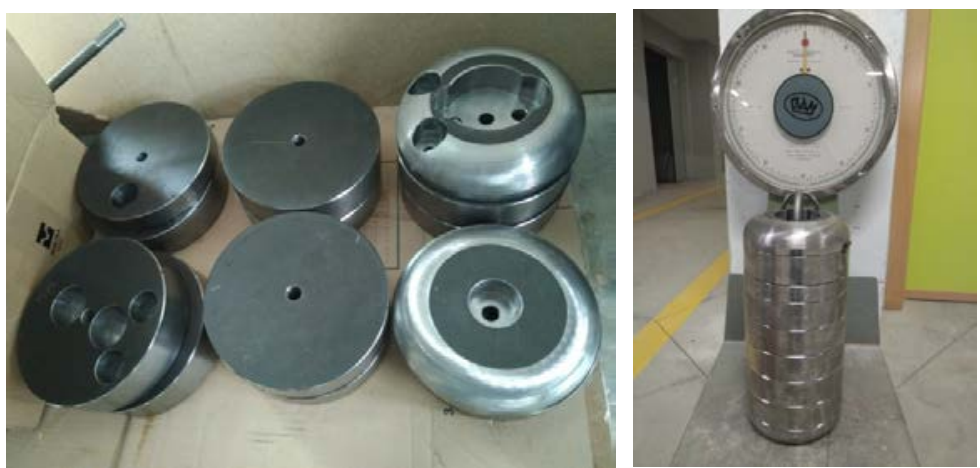

Figure 6: Pieces of the mass and $100 \mathrm{~kg}$ mass.

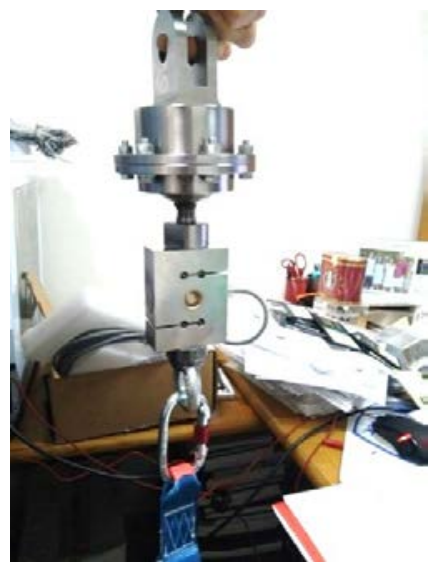

Figure 7: Lanyard and $50 \mathrm{kN}$ load cell attached to spherical ball joint.

\section{INSTRUMENTATION}

A $50 \mathrm{kN}$ load cell was used and connected in series to the spherical joint (Fig. 7) at the Civil Engineering Department Laboratory of Alicante University. The equipment allows to measure between $1.2 \mathrm{kN}$ and $50 \mathrm{kN}$ with an accuracy of $\pm 2 \%$, and a bandwidth of $1000 \mathrm{~Hz}$. 
Software computer equipment: the recorder gives the maximum value with an accuracy of $\pm 1 \%$ and the force / time curve its dynamically calibrated to $\pm 2 \%$ throughout its operating range.

\section{TEST METHOD}

\subsection{Lanyard conditioning}

All tested lanyards and energy absorbers have been subjected to, at least, $24 \mathrm{hr}$. at controlled temperature and humidity conditions: temperature $(23 \pm 5)^{\circ} \mathrm{C}$ and humidity $(65 \pm 5) \%$ (Fig. 8).

\subsection{Planed tests}

The test method chosen is the one described in EN-355 and EN-364 in order to compare the results of a system with and without energy absorber.

In a first battery of tests, object of this paper, we limit to a $1 \mathrm{~m}$ length lanyard and a rigid mass of $100 \mathrm{~kg}$.

Our planning test was the following:

Without energy absorber: (Fig. 9)

Test 1: Fall factor 1, free-fall $1 \mathrm{~m}$.

Test 2: Fall factor 2, free-fall $2 \mathrm{~m}$.

With energy absorber (Fig. 10)

Test 3: Fall factor 1, free-fall $1 \mathrm{~m}$

Test 4: Fall factor 2, free-fall $2 \mathrm{~m}$

In future works we will carry out the same test but with a $2 \mathrm{~m}$ length lanyard and different weights of the falling mass.

\subsection{Dynamic strength}

The $50 \mathrm{kN}$ load cell was attached to the anchor point by the spherical ball joint. One end of set test (lanyard or lanyard and energy absorber) was attached to the load cell by a connector and the other end of the test set by a connector to the rigid test mass (Fig. 11).

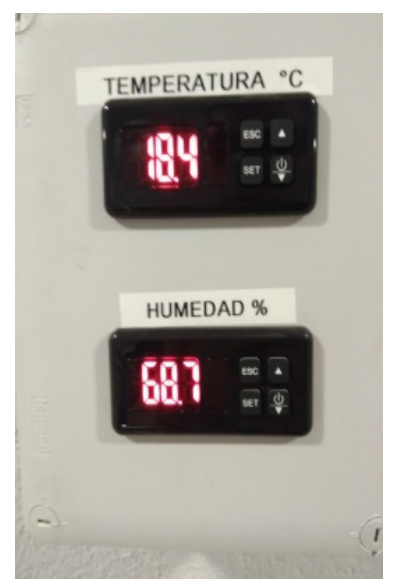

Figure 8: Temperature and humidity conditions. 


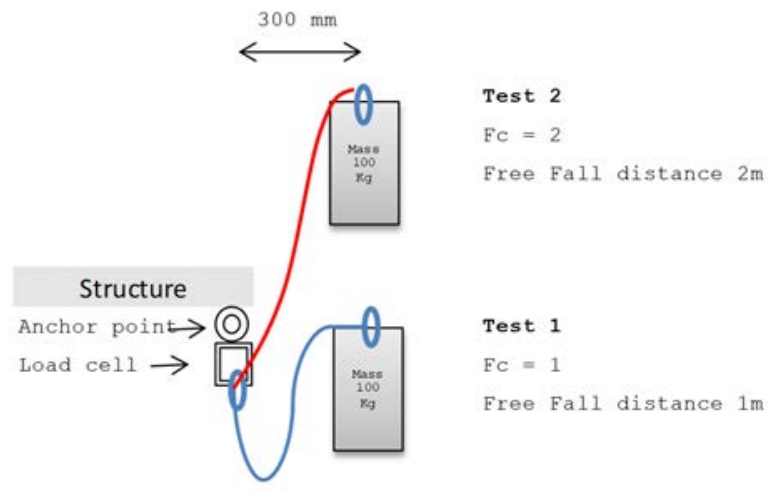

Figure 9: Test setup in accordance to EN-355 (without energy absorber).

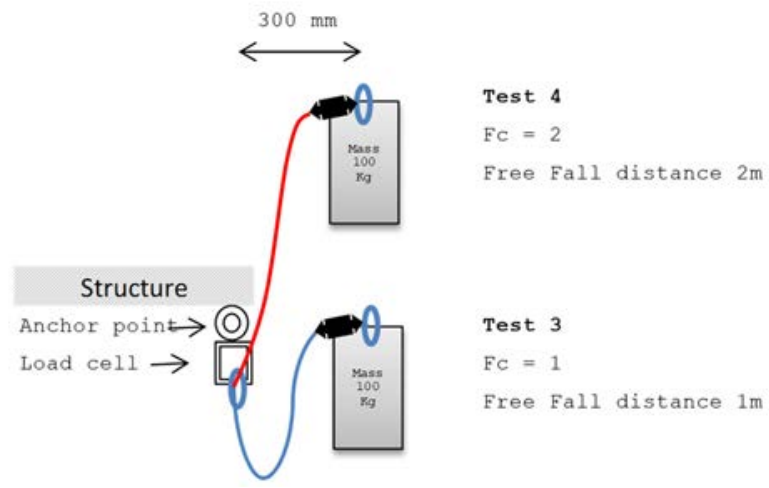

Figure 10: Test setup in acordance to EN-355.
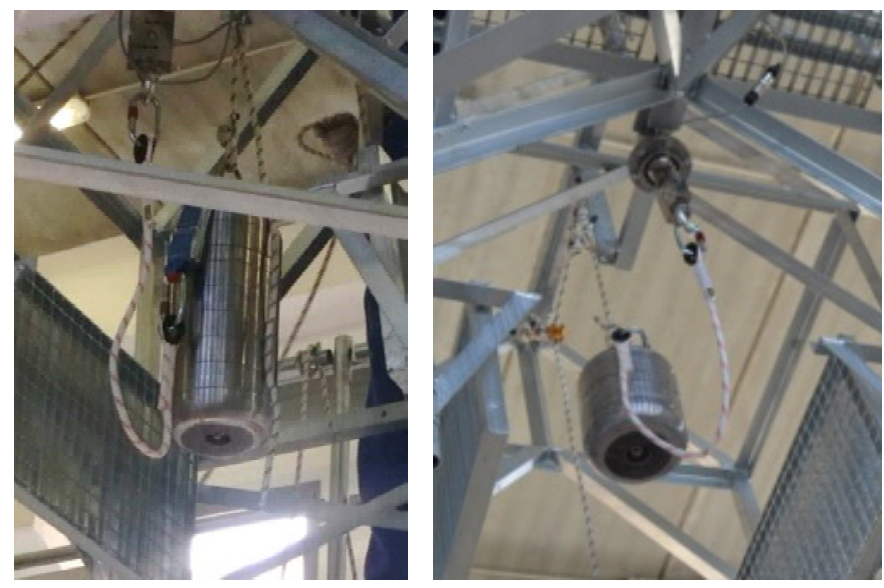

Figure 11: Test method: with and without energy absorber. 
A quick release device was attached to the rigid test mass. The rigid test mass was moved downward until the test set holds the mass. Then the rigid rest mass was raised to 1 or $2 \mathrm{~m}$ free fall distance. In addition, it was hold at $300 \mathrm{~mm}$ horizontally from the anchor point. The rigid test mass was released and it was observed and recorded whether the rigid test mass is arrested. The peak load was recorder at the anchor point. Moreover, we recorded a force/time curve and lanyard and energy absorber extension.

\section{RESULTS}

\subsection{Static strength test of energy absorber}

The relevant results (Fig. 12) were:

Break strength average 5,000 N.

Extension of the energy absorber at the break moment was $0.86 \mathrm{~m}$.

Absorption capacity $4.3 \mathrm{~kJ}$.

\subsection{Dynamic results}

The maximum arrest force and extension of lanyard and energy absorber after testing are presented in Table 2 (average of three impacts under the same conditions, with new test samples each time).

We note that the same equipment (Test 1 and Test 2) presents a reduction of $35 \%$ in the arrest force received by the user when the fall factor is reduced from 2 to 1 . This matches with the analytical work presented by Carrión et al. [13].

The maximum arrest force, which influences the probability of injury [23], allowable in European Standards is $6 \mathrm{kN}$ (Crawford [24]). As we can see (Figs 13 and 14) at Test 1 and Test 2 without energy absorber the maximum arrest force is exceeded. The force / time curves show a series of rebounds after the maximum peak. In the case of fall factor 2 (Fig. 14), the second rebound also exceeds the allowed $6 \mathrm{kN}$. In both cases the force peak is reached in $0.1 \mathrm{~s}$ approximately from the moment the rope comes into tension.

The lanyard, in both cases, is permanently deformed after the test. It suffers the most damage at the points of contact with the connectors. The seams do not break but deform at a $45^{\circ}$ angle.
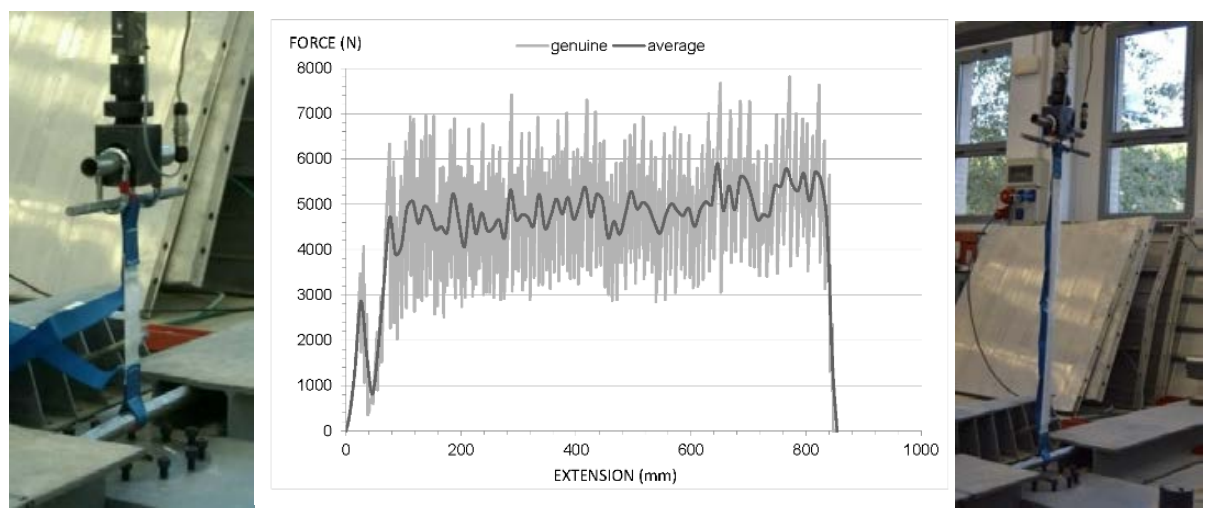

Figure 12: Static strength of energy absorber (first moment, tensile forces process and last moment). 
Table 2: Results. Peak load and extension.

\begin{tabular}{|c|c|c|c|c|c|}
\hline & $\begin{array}{c}\text { Energy } \\
\text { absorber }\end{array}$ & $\begin{array}{c}\text { Free fall } \\
\text { distance }(\mathrm{m})\end{array}$ & $\begin{array}{c}\text { Peak load (N) } \\
\text { at anchorage } \\
\text { point }\end{array}$ & $\begin{array}{c}\text { Lanyard extension } \\
(\mathrm{mm}) \text { post test }\end{array}$ & $\begin{array}{c}\text { Energy absorber } \\
\text { extension (mm) } \\
\text { post test }\end{array}$ \\
\hline TEST 1 & NO & 1 & 9124 & 25 & - \\
\hline TEST 2 & NO & 2 & 14025 & 35 & - \\
\hline TEST 3 & YES & 1 & 3900 & 10 & 520 \\
\hline TEST 4 & YES & 2 & 7675 & 24 & 920 \\
\hline
\end{tabular}

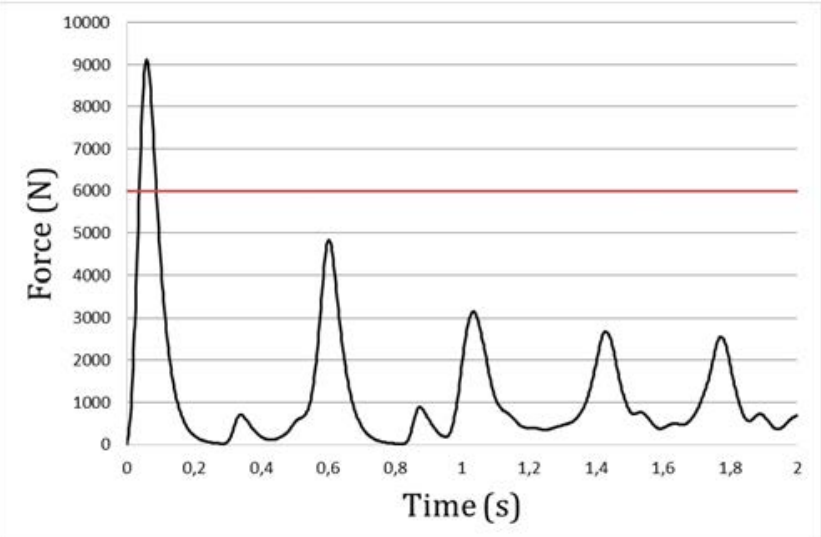

Figure 13: Force / time curve Test 1. Fall factor 1.

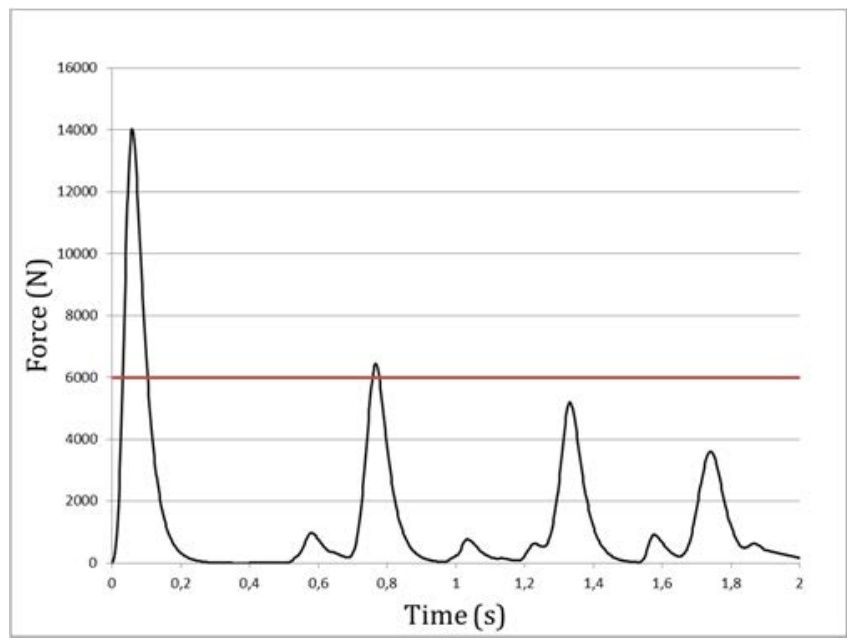

Figure 14: Force / time curve Test 2. Fall Factor 2. 
In the case of Test 3 (fall factor=1, Fig. 16) the entire energy (near $1.5 \mathrm{~kJ}$ ) was absorbed without complete extension of the absorber (Fig. 15). The force peak reached $3.9 \mathrm{kN}$ after a step of quasi constant force near $3.1 \mathrm{kN}$, under the accepted maximum of $6 \mathrm{kN}$. In the vicinity of the maximum force the ballast has a velocity near to zero (to be stopped) and the behaviour of energy absorber tends to static one, with higher strength, as it can be seen in static test (near 5 kN, Fig. 12).

In the case of test 4 (fall factor=2, Fig. 17) the absorber reached its maximum extension and it was not able to absorb the entire energy (near $3 \mathrm{~kJ}$ ). Its crack (Fig. 18) generates a transitory decreasing of force during the time the security band (a few longer) was put in full tension. This element being stiffer than the absorber, a new peak appears similar to tests without absorber until $7.7 \mathrm{kN}$, major than accepted maximum. That reveals an insufficient length of absorber for this fall.

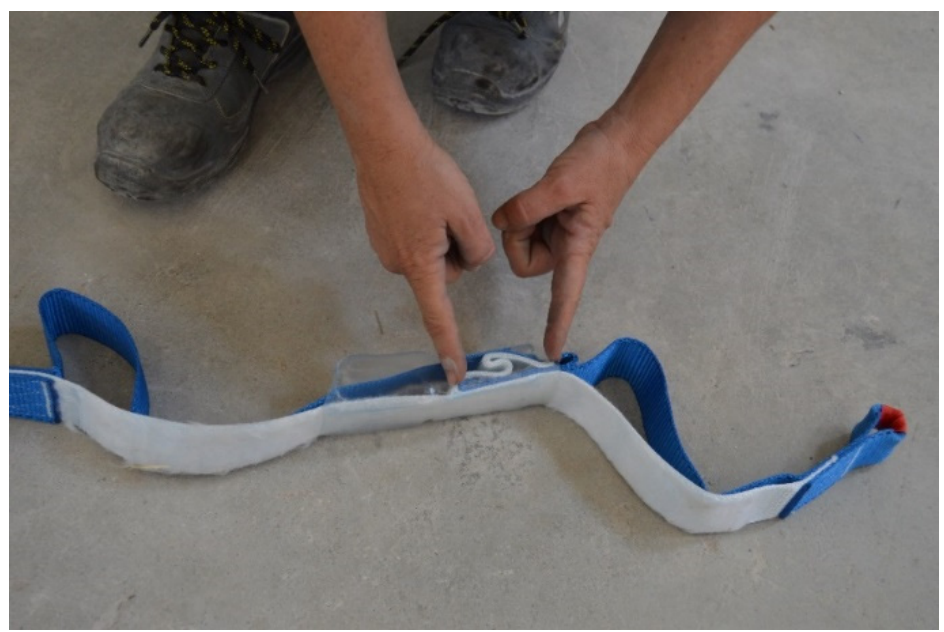

Figure 15: Energy absorber post Test 3.

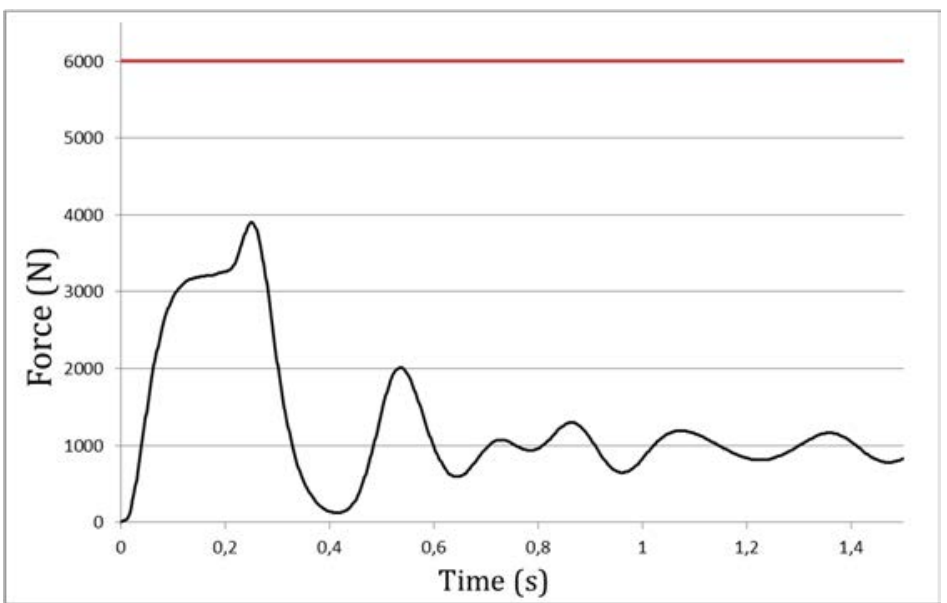

Figure 16: Force / time curve. Test 3. Fall Factor 1. 


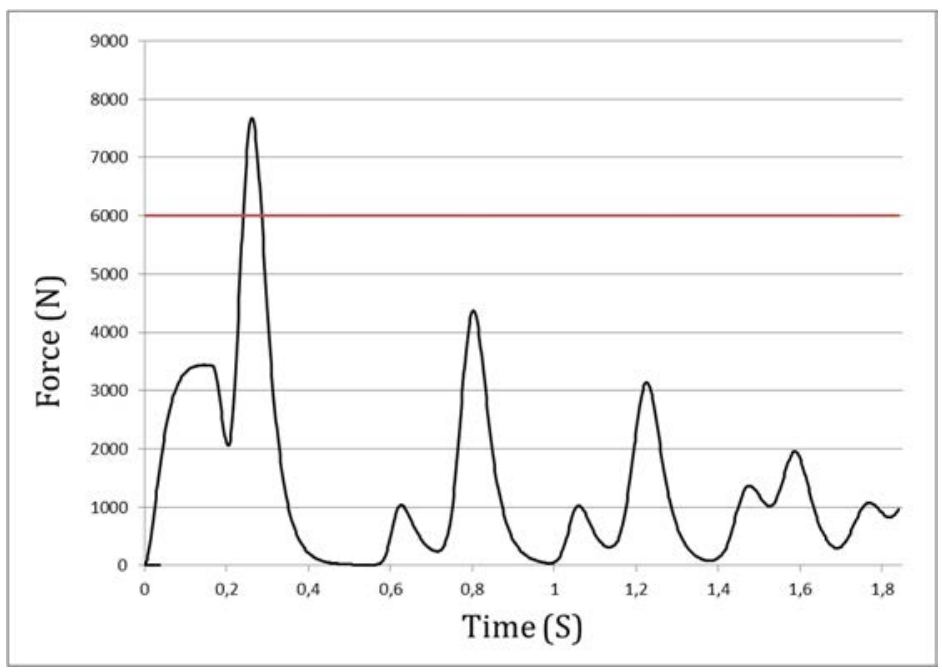

Figure 17: Force / time curve. Test 4. Fall Factor 2.

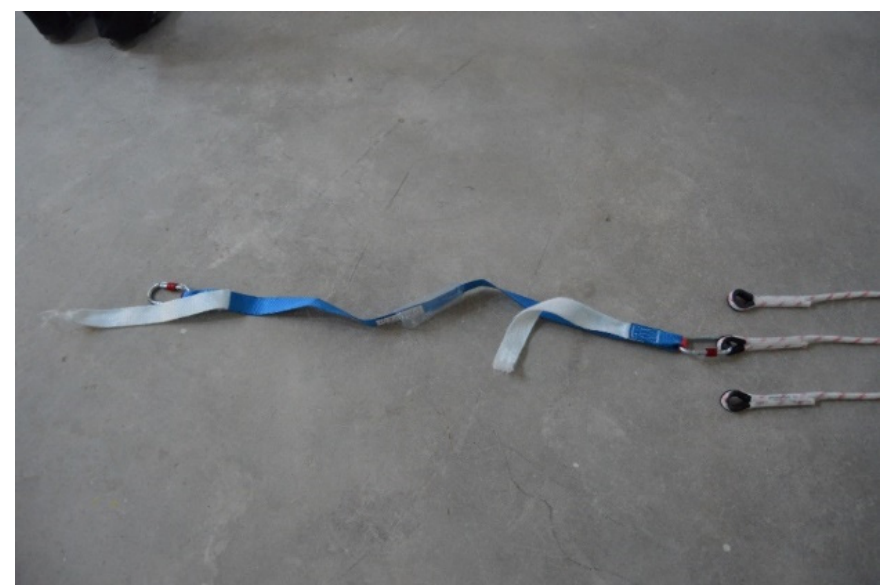

Figure 18: Energy absorber post Test 4.

\section{CONCLUSIONS}

In view of the results, the system composed only of lanyard exceeds the limits established in European standards, exceeding more than twice the allowed arrest force.

The situation of the anchor point with respect to a user can suppose (with the same equipment) a reduction of the force of impact of more than $35 \%$.

The material that the lanyards are composed is not suitable for stopping a fall safely. Manufacturers should value the use of plastic behavior materials in order to reduce the peak of force.

The inclusion of energy absorbers appears as necessary to satisfy the requirement of a maximum force no greater than the accepted $6 \mathrm{kN}$. Without absorber, for fall factor (fall height/length) 1 and 2 the peak forces were 9.1 and $14.0 \mathrm{kN}$, respectively. 
The presence of energy absorber leads to approximately duplicate the duration of velocity loss during retention impact, then to decrease the acceleration and maximum forces.

For fall factor 1 the tested absorber was able to absorb the entire energy, leading to a peak force of $3.9 \mathrm{kN}$, under the accepted maximum value.

For fall factor 2 the absorber was not able to absorb the entire energy, breaking completely and leading to a hard impact due to the security band, with a peak of $7.7 \mathrm{kN}$, greater than accepted maximum. For this fall factor the absorber must be longer.

The authors have tested systems of individual protection against falls (without harness) and as they are used by the workers, arriving at really worrying conclusions in the sense that the system formed by certified equipment put on the market (Test 4 ) goes beyond the limits established in European standards.

The conclusions obtained here will be communicated to the pertinent standard authorities.

\section{ACKNOWLEDGEMENTS}

This research has been possible thanks to the scholarships of Foundation Prevent and Valencian Generality GV/2017/181 and to the collaboration of Civil Engineering Department from Alicante University.

\section{REFERENCES}

[1] Asociación Española de Normalización, 2009. UNE-EN 363:2009, Personal fall protection equipment. Personal fall protection systems. AENOR, Madrid.

[2] Wang, C.H., Free fall restraint systems. Professional Safety - ASSE Journal, 22(2), 1977.

[3] Steinberg, H.L., NBSIR 76-1146 A Study of Personal Fall-Safety Equipment. Washington, D.C., National Bureau of Standards, 1977.

[4] Microys, H.F., Climbing ropes. American Alpine Journal, 21(1), pp. 130-147, 1977.

[5] Sulowski, A.C., assessing fall arresting system effectiveness. Parts 1 and 2. National Safety News, 123(3)-(4), 1981.

[6] Brinkley, J.W. \& Sulowski, A.C., Measurement of maximum arrest force in performance test of fall protection equipment. Journal of Testing and Evaluation. S.l.: JTEVA, 18(2), pp. 123-127, 1990.

[7] Irles, R., González, A., Segovia, E. \& Maciá, A., Las redes verticales de seguridad en la construcción de edificios I. Informes de la Construcción, 53(477), 2002.

[8] Segovia, E., Irles, R., González, A., Maciá, A. \& Pomares, J.C., Las redes verticales de seguridad en la construcción de edificios II. Informes de la Construcción, 59(505), pp. 37-51, 2007.

[9] Segovia, E., Thesis doctoral: Criterios para el diseño de los sistemas anticaída utilizados en construcción y sometidos a impacto, Universidad Politécnica de Valencia, Sept. 2004.

[10] Pomares, J.C., Irles, R., Segovia, E. \& Boixader, D., Barandillas de protección personal con solicitación dinámica. Informes de la Construcción, 65(530), pp. 241-251, 2013.

[11] Pomares, J.C., Irles, R., Segovia, E. \& Ferrer, B., Acceleration and deflection analysis for class C edge protection systems (EN 1374-2013) in construction works. Journal of Construction Engineering, 140(8), pp. 31-1-31-7, 2014.

[12] Pomares, J.C., Irles, R., Carrión, E.A., González, A. \& Segovia, E.G., Previous numerical studies with deformable ballast on body impacts against building edge protection systems. International Journal of Computational Methods and Experimental Measurements, 4(3), pp. 280-287, 2016. DOI: 10.2495/CMEM-V4-N3280-287. 
[13] Carrión, E.A., Irles, R., Segovia, E.G. \& Pomares, J.C., Personal fall arrest systems under impact. Numerical simulations. Informes de la Construcción, 68(542), pp. 1-10, 2016.

[14] Carrión, E.A., Saez, P.I. \& Mora-García, R.T., Sistemas de protección individual contra caídas: Legislación, Definiciones y Equipos. Publicaciones de la Universidad de Alicante: Alicante, 2014.

[15] American Society of Safety Engineers, ANSI A10.32-2004. Fall Protection SystemsAmerican National Standard for Construction and Demolition Operations, ASSE: Illinois, 2004.

[16] American Society of Safety Engineers/American National Standards Institute, Z359.12007 Safety Requirements for Personal Fall Arrest. Systems, Subsystems and Components, ANSI/ASSE: Illinois, 2007.

[17] American Society of Safety Engineers/American National Standards Institute, Z359.13-2009 Personal Energy Absorbers and Energy Absorbing Lanyards, ANSI/ASSE: Illinois, 2009.

[18] International Organization for Standardization, ISO 10333-2:2000. Personal fall-arrest systems - Part 2: Lanyards and energy absorbers, ISO: Geneva, 2000.

[19] Asociación Española de Normalización, UNE-EN 355:2002, Personal protective equipment against falls from a height Energy absorbers, AENOR: Madrid, 2002.

[20] Asociación Española de Normalización, UNE-EN 354:2011, Personal fall protection equipment. Lanyards. AENOR: Madrid, 2011.

[21] Asociación Española de Normalización, UNE-EN 362:2005, Personal protective equipment against falls from a height. Connectors. AENOR: Madrid, 2005.

[22] Asociación Española de Normalización, UNE-EN-364:1993, Personal protective equipment against falls from a height. Test methods. AENOR: Madrid, 1993.

[23] Eiband, A.M., Human tolerance to rapidly applied accelerations, A summary of the literature. NASA Memorandum 5-19-59E, NASA: Washington, DC, 1959.

[24] Crawford, H., HSL/2003/09 Survivable Impact Forces on Human Body Constrained by Full Body Harness. Health and Safety Executive. www.hse.gov.uk/. Accessed on: 14 Apr. 2018. 